\title{
PENERAPAN MODEL PEMBELAJARAN INKUIRI UNTUK MENINGKATKAN KEMAMPUAN MENGANALISIS UNSUR INTRINSIK CERPEN PADA PESERTA DIDIK KELAS XI MIA 10 SMA NEGERI 7 DENPASAR TAHUN PEMBELAJARAN 2018/2019
}

\author{
Cokorde Istri Mirah Kusuma Widiawati \\ Guru Bahasa Indonesia, SMA Negeri 7 Denpasar \\ Email : cokmirah77@gmail.com
}

\begin{abstract}
ABSTRAK
Tujuan dalam penelitian ini adalah untuk mengetahui apakah penerapan model pembelajaran inkuiri dapat meningkatkan kemampuan menganalisis unsur intrinsik cerpen dan dapat meningkatkan respon peserta didik. Penelitian ini menggunakan rancangan penelitian tindakan kelas (PTK), ada empat komponen penting dalam siklus PTK yaitu: (1) tahap perencanaan, (2) tahap tindakan, (3) tahap observasi dan, (4) tahap refleksi. Penelitian ini dilaksanakan pada semester ganjil bulan Agustus sampai September 2018. Subjek penelitian adalah peserta didik kelas XI MIPA 10 SMA Negeri 7 Denpasar tahun pelajaran 2018/2019 dengan jumlah peserta didik sebanyak 36 orang. Objek penelitian tindakan kelas ini adalah kemampuan menganalisis unsur intrinsik cerpen.Hasil penelitian ini menunjukkan meningkatnya kemampuan menganalisis teks cerpen.Pemerolehan nilai rata-rata kelas pada refleksi awal sebesar 65,64 terjadi peningkatan pada siklus I menjadi 73,42 dan pada siklus II menjadi meningkat menjadi 82,03. Peningkatan nilai dari siklus I ke siklus II terjadi pada peserta didik 28 orang atau 77,78 \%. Persentase keberhasilan peserta didik dalam belajar menganalisis unsur intrinsik cerpen mencapai ketuntasan klasikal 94,44\% dari jumlah peserta didik memperoleh nilai 70 ke atas. Penerapan model pembelajaran inkuiri dalam pembelajaran menganalisis unsur intrinsik teks cerpen mendapat respon yang positif dari peserta didik. Pemerolehan nilai rata-rata respon kelas pada siklus I adalah 69,12 dan pada siklus II meningkat menjadi 84,31.Persentase respon peserta didik dalam pembelajaran menganalisis unsur intrinsik cerpen dengan penerapan model pembelajaran inkuirimencapai ketuntasan klasikal yaitu 94,44\% .
\end{abstract}

Kata Kunci : Model pembelajaaran inkuiri, Kemampuan menganalisis, Cerpen, Hasil belajar.

\section{ABSTRACT}

The purpose of this research is to find out whether the application of inquiry learning models can improve the ability to analyze short story intrinsic elements and can improve students' responses. This study uses a class action research design (PTK), there are four important components in the PTK cycle, namely: (1) the planning stage, (2) the stage of action, (3) the stage of observation and, (4) the stage of reflection. This research was carried out in the odd semester of August to September 2018. The research subjects were students of class XI MIPA 10 in SMA Negeri 7 Denpasar in the academic year 2018/2019 with a total of 36 students. The object of this class action research is the ability to analyze short story intrinsic elements. The results of this study indicate the increased ability to analyze short story texts. The acquisition of the class average value at the initial reflection of 65.64 increased in the first cycle to 73.42 and in the second cycle it increased to 82.03. The increase in value from cycle I to cycle II occurs in 28 students or $77.78 \%$. The percentage of success of students in learning to analyze the intrinsic elements of short stories reaches classical completeness $94.44 \%$ of the number of students get 70 and above. The application of the inquiry learning model in learning analyzes the 
intrinsic elements of the short story gets a positive response from students. The acquisition of the average class response value in the first cycle is 69.12 and in the second cycle it increases to 84.31. Percentage of response of students in learning to analyze the intrinsic elements of short stories with the application of inquiry learning models achieving classical completeness, namely $94.44 \%$.

Keywords: Model of inquiry learning, ability to analyze, short stories, learning outcomes.

\section{PENDAHULUAN}

Pendidikan adalah suatu usaha atau kegiatan yang dijalankan dengan sengaja, teratur dan berencana dengan maksud mengubah atau mengembangkan perilaku yang diinginkan. Sekolah sebagai lembaga formal merupakan sarana dalam rangka pencapaian tujuan pendidikan tersebut. Melalui sekolah, peserta didik belajar berbagai macam hal. Dalam pendidikan formal, belajar menunjukkan adanya perubahan yang sifatnya positif sehingga pada tahap akhir akan didapat keterampilan, kecakapan dan pengetahuan baru. Hasil dari proses belajar tersebut tercermin dalam prestasi belajarnya. Namun dalam upaya meraih prestasi belajar yang memuaskan dibutuhkan proses belajar yang baik.

Proses belajar yang terjadi pada individu memang merupakan sesuatu yang penting, karena melalui belajar individu mengenal lingkungannya dan menyesuaikan diri dengan lingkungan disekitarnya. Belajar merupakan proses perubahan dari belum mampu menjadi mampu dan terjadi dalam jangka waktu tertentu. Dengan belajar, peserta didik dapat mewujudkan cita-cita yang diharapkan. Belajar akan menghasilkan perubahan-perubahan dalam diri seseorang. Belajar Bahasa Indonesia dalam materi pelajaran sastra, dimana sastra merupakan karya fiksi yang dibuat oleh pengarang berdasarkan pengalamannya, atau orang lain serta kondisi masyarakat sekitar. Sastra juga merupakan luapan emosi yang spontan, yang mampu mengungkapkan aspek-aspek estetik baik yang didasarkan aspek kebahasaan maupun aspek makna. Karya sastra sebagai bentuk dan hasil sebuah pekerjaan kreatif, pada hakikatnya adalah suatu media yang mendayagunakan bahasa untuk mengungkapkan tentang kehidupan manusia. Oleh sebab itu, sebuah karya sastra pada umumnya berisi tentang rutinitas kehidupan serta gejala-gejala sosial yang terjadi dimasyarakat. Sastra menurut Sumardjo (1997:3), ungkapan pribadi manusia yang berupa pengalaman, pemikiran, perasaan, ide, semangat, keyakinan, dalam suatu bentuk gambaran konkrit yang membangkitkan pesona dengan alat bahasa.

Sastra merupakan wujud gagasan seseorang melalui pandangan terhadap lingkungan sosial yang berada di sekelilingnya dengan menggunakan bahasa yang indah. Sastra hadir sebagai hasil perenungan pengarang terhadap fenomena yang ada. Dengan mempelajari sastra seseorang mampu untuk mempelajari masalah yang terjadi disekitar, memecahkan masalah dan mendapatkan kepuasan batin tersendiri dari karya sastra tersebut. Salah satu teks genre sastra dalam kurikulum 2013 yang sering dipergunakan dalam pembelajaran Bahasa Indonesia adalah 
cerpen. Cerpen adalah suatu cerita yang menggambarkan sebagian kecil dari keadaan, peristiwa kejiwaan, dan kehidupan seseorang (Karmini, 2011:102). Sejalan dengan pendapat Karmini, menurut Kosasih (2012:34), cerpen adalah cerita yang bentuk fisiknya pendek. Cerpen merupakan karya fiksi yang dibangun melalui berbagai unsur instrinsik. Unsur-unsur tersebut dipadukan dan dibuat mirip dengan dunia nyata yang lengkap dengan peristiwa-peristiwa di dalamnya sehingga tampak benar-benar ada dan terjadi. Unsur intrinsik inilah yang secara langsung membangun sebuah cerita. Keterpaduan berbagai unsur intrinsik akan menjadikan sebuah cerpen indah dan menarik untuk dibaca, apalagi jika pengarang mampu menuangkannya dalam bahasa yang memikat.

Dengan menganalisis unsur intrinsik peserta didik sudah masuk ke dalam proses apresiasi sastra. Menurut Hayati dan Muchlich (tt:5), istilah apresiasi berasal dari bahasa Inggris apreciaton yang berarti penghargaan, penilaian, dan pengertian. Dengan begitu kegiatan memberikan penghargaan pada karya sastra berupa analisis interpresi ataupun menilai baik buruknya sebuah karya sastra dapat digolongkan dalam mengapresiasi. Sejalan dengan pendapat Hayati dan Muchlich, Gove (dalam Aminuddin,2013:34), istilah apresiasi sastra mengandung makna (1) pengenalan melalui perasaan atau kepekaan batin dan (2) pemahaman dan pengakuan terhadap nilai-nilai keindahan yang diungkapkan pengarang. Dengan menganalisis cerpen seseorang akan mendapatkan informasi yang memadai unsur pembangun sebuah cerpen. Dengan mempelajari cerpen seorang peserta didik mampu untuk menceritakan kembali pengalamannya dalam bentuk fiksi atau seseorang mampu untuk melukiskan kehidupan atau fenomena sekitarnya dalam balutan fiksi dengan pengunaan bahasa yang baik. Unsur intrinsik merupakan unsur utama pembangun cerpen untuk itu diharapkan peserta didik mampu untuk memahami, mengidentifikasi, dan menganalisis unsur intrinsik dengan baik agar peserta didik bisa mengaplikasikan dalam bentuk tulisan serupa yaitu cerpen ataupun mengambil hikmah dari inti cerita ataupun pesan moral yang disampaikan pengarang.

Berdasarkan observasi awal dengan teknik wawancara yang dilakukan peneliti diperoleh informasi dari guru bahasa Indonesia di SMA Negeri 7 Denpasar kelas XI MIPA10 kemampuan menganalisis cerpen cenderung rendah. Dua hal yang menjadi fokus masalah yang ditemukan peneliti, yakni kemampuan menganalisis unsur intrinsik cerpen masih kurang dan respon peserta didik cenderung kurang fokus saat mengikuti pelajaran. Mengingat pembelajaran menganalisis unsur instrinsik cerpen itu sudah diajarkan, maka tentunya peserta didik sudah mendapatkan pemahaman yang memadai tentang bagaimana menganalisis intrinsik yang meliputi tema, alur, tokoh, penokohan, latar, sudut pandang, gaya bahasa, dan amanat. Namun, pada kenyataannya nilai peserta didik dalam menganalisis struktur teks terbilang rendah. Hal ini terlihat dari nilai hasil menganlisis unsur intrinsik cerpen yakni 65. Kenyataan ini terlihat ketika peneliti observasi awal dengan teknik 
wawancara yang dilakukan peneliti diperoleh informasi dari guru bahasa Indonesia kelas XI MIPA 10 SMA Negeri 7 Denpasar kemampuan menganalisis unsur intrinsik cerpen rendah. Peserta didik tidak mampu membedakan tema mayor dan minor, keliru menentukan majas, dan sudut pandang. Respon peserta didik pun terbilang kurang baik seperti keaktifan dan perhatian masih terbilang kurang.

Setelah melakukan observasi peneliti menemukan hal penyebab kurangnya kemampuan dan respon peserta didik yang tidak baik pada saat menganalisis unsur intrinsik cerpen yakni (1) kurangnya perhatian peserta didik dalam mengikuti pelajaran terbukti dengan masih banyaknya peserta didik yang mengobrol saat pelajaran berlangsung, (2) masih kurangnya pengetahuan peserta didik terhadap materi cerpen khususnya tentang menganalisis unsur intrinsik cerpen, (3) pada saat penyampaian materi guru cenderung menggunakan model pembelajaran yang menonton seperti ceramah dan jarang adanya diskusi. Dengan kata lain guru masih aktif memberikan penjelasan dan peserta didik hanya mendengarkan saja. Masalah di atas terbilang cukup serius. Untuk itu sebagai guru bahasa Indonesia, peneliti merasa berkewajiban untuk menyikapi dan meningkatkan kemampuan peserta didik dalam menganalisis unsur intrinsik cerpen. Adapun solusi yang ditawarkan peneliti adalah memilih model pembelajaran yang tepat sehingga proses hasil belajar mengajar bisa tercapai. Memilih metode yang cocok sesuai dengan kebutuhan peserta didik memang tidaklah mudah. Untuk itu, dengan berbagai pertimbangan peneliti akhirnya memilih model pembelajaran inkuiri.Model pembelajaran inkuiri adalah model pembelajaran penemuan. Peserta didik akan dituntut untuk menemukan serta mencari jawaban atas suatu permasalahan yang tentunya dilakukan dengan cara sistematis, logis dan kritis dan dianalisis dengan perhitungan yang matang. Menyimak ulasan tersebut, model pembelajaran inkuiri jelas akan lebih menjadikan peserta didik untuk selalu terlibat dan banyak berdiskusi dalam penerapannya. Guru disini hanya menjadi seorang fasilitator selebihnya peserta didik yang lebih berperan. Berkenaan dengan model pembelajaran inkuiri, ada dua macam jenis model ini yaitu model pembelajaran inkuiri terbimbing dan model pembelajaran inkuiri terikat.

Dengan demikian, peserta didik akan terlibat aktif memecahkan masalah tentu dengan bimbingan guru dan pola pembelajaran yang menyenangkan. Dengan pembelajaran inkuiri, peserta didik diajarkan disiplin dan keterampilan intelektual untuk memecahkan masalah serta memiliki rasa ingin tahu yang tinggi. Model pembelajaran inkuiri menekankan kepada aktivitas peserta didik secara maksimal untuk mencari dan menemukan, artinya model pembelajaran inkuiri menempatkan peserta didik sebagai subjek belajar. Dalam proses pemebelajaran, peserta didik tidak hanya berperan sebagai penerima pelajaran melalui penjelasan guru secara verbal, tetapi mereka berperan untuk menemukan sendiri inti dari materi pelajaran itu sendiri. Karakteristik dari Model Pembelajaran Inkuiri: (1) menekankan kepada proses mencari dan menemukan, (2) pengetahuan dibangun oleh peserta didik melalui proses pencarian, (3) 
peran guru sebagai fasilitator dan pembimbing peserta didik dalam belajar, (4) menekankan pada proses berpikir kritis dan analitis untuk merumuskan kesimpulan. Untuk menciptakan karakteristik seperti itu, maka peranan guru sangat menentukan. Guru tidak lagi berperan sebagai pemberi informasi dan peserta didik sebagai penerima informasi, sekalipun hal ini sangat diperlukan. Dalam model pembelajaran inkuiri, guru dituntut untuk membantu membina dan mengembangkan kemampuan menganalisis peserta didik. Keberhasilan belajar peserta didik akan sangat ditentukan oleh kemampuan dan kemauan untuk bisa memecahkan masalah hal ini sangat memengaruhi keluasan pandangan tentang berbagai masalah. Oleh karena itu, pembelajaran dengan mengunakan model pembelajaran inkuiri diyakini mampu meningkatkan kemampuan menganalisis peserta didik serta berpengaruh terhadap respon peserta didik. Ketika seorang guru Bahasa Indonesia akan mengajar teknik pembelajaran menulis laporan hasil pengamatan dengan model pembelajaran inquiri maka kegiatan pembelajarannya harus mengarah pada enam tahapan pembelajaran Inquiri, yaitu (1) merumuskan masalah, (2) merumuskan hipotesis, (3) menguji jawaban, (4) menarik kesimpulan, (5) menerapkan kesimpulan, dan (6) menulis laporan.

Tujuan dari penelitian ini adalah untuk mengetahui apakah penerapan model pembelajaran inkuiri dapat meningkatkan kemampuan menganalisis unsur intrinsik cerpen peserta didik kelas XI MIPA 10 SMA Negeri 7 Denpasar tahun pelajaran 2018/2019 dan apakah penerapan model pembelajaran inkuiri dapat meningkatkan respon peserta didik kelas XI MIPA 10 SMA Negeri 7 Denpasar tahun pelajaran 2018/2019 dalam belajar menganalisis unsur intirnsik cerpen.

\section{METODE PENELITIAN}

1. Rancangan Penelitian.

Penelitian ini menggunakan rancangan penelitian tindakan kelas (PTK), karena penelitian ini berupaya untuk memperbaiki dan meningkatkan kualitas belajar mengajar di dalam kelas. Penelitian tindakan kelas ini akan dilakukan dalam beberapa siklus hingga hasilnya mencapai hasil yang baik untuk mengetahui apakah penerapan model pembelajaran Inkuiri dapat meningkatkan kemampuan menganalisis unsur intrinsik cerpen pada peserta didik kelas kelas XI MIPA 10 SMA Negeri 7 Denpasar tahun pelajaran 2018/2019. Ada empat komponen penting dalam siklus penelitian yaitu: (1) tahap perencanaan, (2) tahap tindakan, (3) tahap observasi dan, (4) tahap refleksi.

\section{Setting Penelitian}

Dalam setting penelitian tindakan kelas (PTK) ini, akan dibahas dua hal, yakni: (1) tempat dan waktu penelitian. Penelitian ini dilaksanakan di kelas XI MIPA 10 SMA Negeri 7 Denpasar, J1. Kamboja No.9, Dangin Puri Kangin, Denpasar Utara, Kota Denpasar, Bali 80236 pada Tahun Pelajaran 2018/2019 untuk mata pelajaran Bahasa Indonesia. Topik yang akan diteliti adalah kemampuan menganalisis unsur intrinsik cerpen yang terdiri atas tema, alur/plot, tokoh dan penokohan, latar/setting, sudut pandang, pesan/amanat. Waktu penelitian yang dilaksanakan pada semester ganjil pada bulan Agustus sampai September 2018. 
Penentuan waktu penelitian ini mengacu pada kalender akademik sekolah.

\section{Subjek dan Objek Penelitian}

Subjek penelitian adalah orang yang akan dikenai tindakan dalam penelitian yang akan dilakukan. Dalam penelitian ini yang menjadi subjek penelitian adalah peserta didik kelas XI MIPA 10 SMA Negeri 7 Denpasar tahun pelajaran 2018/2019 dengan jumlah peserta didik sebanyak 36 orang yang terdiri atas 16 orang laki-laki dan 20 orang perempuan. Objek penelitian tindakan kelas ini adalah kemampuan menganalisis unsur intrinsik cerpen. Unsur intrinsik yang dimaksud adalah tema, alur/plot, setting/latar, tokoh dan penokohan, sudut pandang dan amanat, melalui model pembelajaran Inkuiri.

4. Prosedur Penelitian
Penelitian tindakan kelas (PTK) atau classroom action research (CAR). Dari namanya sudah menunjukan isi yang terkandung di dalamnya, yaitu sebuah penelitian yang dilakukan di kelas. Penelitian Tindakan Kelas (PTK) suatu bentuk penelitian reflektif dan kolektif yang dilakukan oleh peneliti untuk meningkatkan penalaran praktik sosial mereka. Ada empat tahapan penting dalam penelitian tindakan kelas, yaitu: (1) perencanaan, pelaksanaan, (3) pengamatan, (4) refleksi. Adapun rincian mengenai prosedur penelitian yang ditempuh adalah sebagai berikut:

Secara lebih rinci langkah-langkah kegiatan tindakan kelas menurut Arikunto, dkk (2012:16) yang dilakukan pada masingmasing siklus dapat digambarkan sebagai berikut.

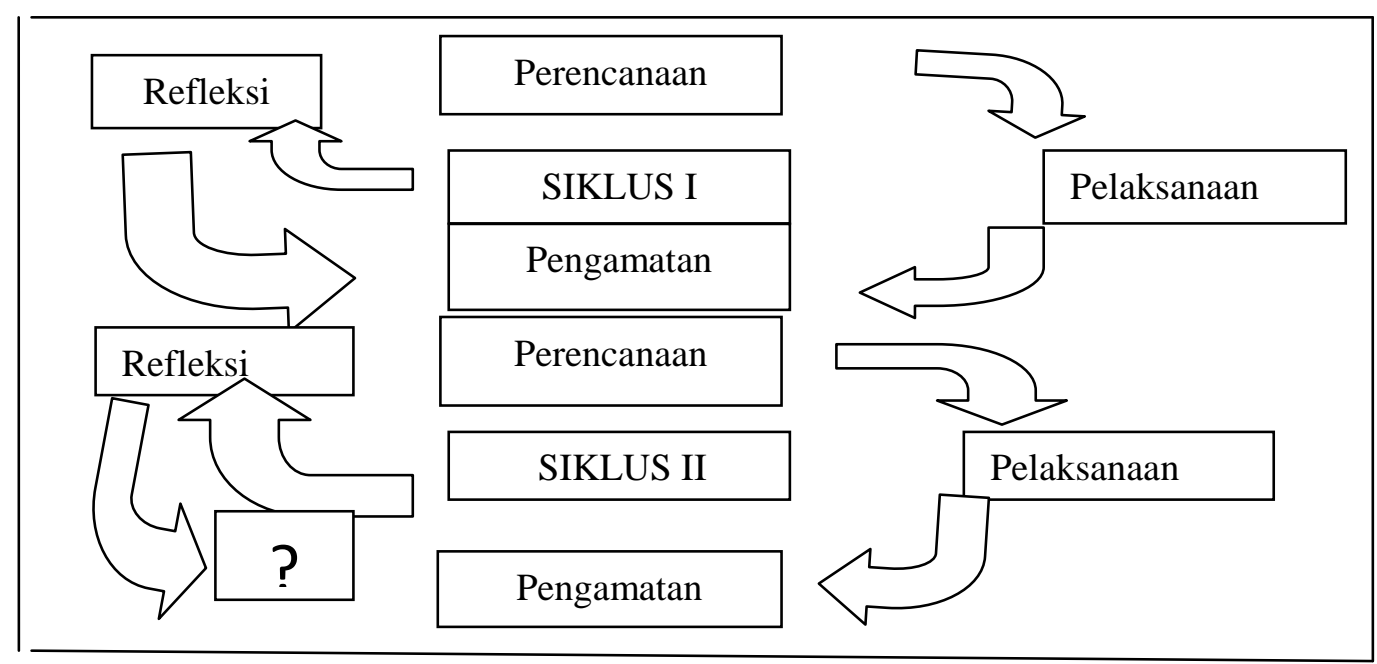

Gambar Siklus Penelitian Tindakan Kelas

5. Metode Pengumpulan Data

Prinsip pengumpulan data dalam penelitian tindakan kelas tidak jauh berbeda dengan prinsip pengumpulan data pada jenis penelitian yang lain, dengan kata lain, prinsip pengumpulan data pada penelitian formal dapat diterapkan pada penelitian tindakan kelas. Pada umumnya dalam penelitian tindakan kelas, baik data kualitatif maupun data kuantitatif dimanfaatkan untuk 
menggambarkan perubahan yang terjadi. Perubahan pada kinerja guru, hasil belajar peserta didik, perubahan kinerja peserta didik, perubahan susana kelas. Metode pengumpulan data yang digunakan dalam penelitian ini adalah metode tes, dan observasi.

\section{Metode Analisis Data}

Setelah semua data terkumpul, maka langkah selanjutnya adalah mengolah data dengan metode analisis statistik deskriptif. Menurut Sugiyono (2014:207) statistik deskriptif adalah satistik yang digunakan untuk menganalisis data dengan cara mendeskripsikan atau menggambarkan data yang telah terkumpul sebagaiman adanya tanpa bermaksud membuat kesimpulan yang berlaku untuk umum atau generalisasi. Data yang diolah hanyalah data umum. Data yang diolah hanyalah data utama yaitu hasil tes kemampuan menganalisis unsur intrinsik cerpen.

Untuk mengetahui adanya peningkatan kemampuan menganalisis unsur intrinsik cerpen dengan penerapan model pembelajaran inkuiri dilakukan dengan membandingkan hasil belajar peserta didik yang dicapai pada siklus I dan siklus II. Langkah-langkah yang dilakukan dalam menganalisis hasil belajar yaitu (1) mengubah skor mentah menjadi skor standar, (2) menentukan kategori kemampuan, (3) mencari skor ratarata.Untuk mengkonversikan skor mentah menjadi skor standar dengan norma skala seratus (persentil) digunakan rumus sebagai berikut.

$$
P=\frac{X}{S M I} x 100
$$

Keterangan

$$
\begin{aligned}
& \mathrm{P}=\text { Persentil } \\
& \mathrm{X}=\text { Skor yang dicapai } \\
& \mathrm{SMI}=\text { Skor Minimal Ideal }
\end{aligned}
$$

Skor rata-rata dihitung dengan rumus :

$$
M=\frac{\sum f . x}{N}
$$

Keterangan :

$$
\begin{array}{ll}
\mathrm{M} & =\text { Mean (rata-rata) } \\
\sum \mathrm{fx} & =\text { Jumlah skor } \\
\mathrm{N} & =\text { Jumlah Individu }
\end{array}
$$

\section{Analisis Data Respon Peserta Didik}

Untuk mengetahui skor respon peserta didik terhadap penerapan model pembelajaran inkuiriuntuk meningkatkan kemampuan menganalisis unsur intrinsik cerpen dalam tiap siklusnya, maka digunakan metode observasi. Penilaian respon peserta didik dalam metode observasi digunakan rumus yang sama dengan cara mengolah data pada kemampuan menganalisis unsur intrinsik cerpen tes SMI (Skor Maksimal Ideal).

\section{Indikator Keberhasilan}

Penelitian terhadap penerapan model pembelajaran inkuiri untuk meningkatkan kemampuan menganalisis unsur intrinsik cerpen berbahasa Indonesia dikatakan berhasil apabila terjadi peningkatan perbaikan kualitas pembelajaran yang dicapai oleh peserta didik akibat dari tindakan yang diberikan. Hal ini dapat dilihat dari hasil penelitian, yaitu sebagai berikut: sebanyak $75 \%$ dari jumlah peserta 
didik harus tuntas atau memiliki nilai ratarata kelas lebih besar atau sama dengan KKM (Kriteria Ketuntasan Minimum).

\section{HASIL DAN PEMBAHASAN}

Pada bagian ini, akan dikemukakan hasil penelitian dari refleksi awal, siklus I, dan siklus II. Subjek penelitian ini adalah peserta didik kelas XI MIPA 10 SMA Negeri 7 Denpasar yang berjumlah 36 orang. Sebagai hasil dari perencanaan tindakan tersebut, peneliti memperoleh data yang diperlukan untuk mengvaluasi hasil penelitian tindakan kelas ini. Data yang diperoleh berupa data hasil tes kemampuan menganalisis unsur intrinsik teks cerpen. Peneliti juga memperoleh data observasi yang digunakan dalam menentukan aspek penilaian respon peserta didik terhadap penerapan model pembelajaran inkuiriuntuk meningkatkan kemampuan menganalisis unsur intrinsik teks cerpen.

Tabel 01 Hasil Menganalisis Unsur Intrinsik Cerpen pada Peserta didik kelas XI MIPA 10 SMA Negeri 7 Denpasar Sebelum Menerapkan Model Pembelajaran Inkuiri

\begin{tabular}{lccc}
\hline & Prasiklus & $\begin{array}{l}\text { Siklus } \\
\text { I }\end{array}$ & Siklus II \\
& & 2.643 & 2.953 \\
\hline Nilai & 2.363 & $2.63,42$ & 82,03 \\
\hline Rata- & 65,64 & 73,45 \\
Rata & & & \\
\hline
\end{tabular}

Tabel di atas menunjukan melalui penerapan model pembelajaran inkuiri dapat meningkatkan kemampuan menganalisis teks cerpen, ini terbukti dari: (1) Pemerolehan nilai rata-rata kelas pada refleksi awal sebesar 65,64 terjadi peningkatan pada siklus 1 menjadi 73,42 dan pada siklus II menjadi meningkat menjadi 82,03 (2) Peningkatan nilai dari siklus I ke siklus II terjadi pada peserta didik 28 orang atau 77,78\%.

Persentase keberhasilan peserta didik dalam belajar menganalisis unsur intrinsik cerpen mencapai ketuntasan klasikal 94,44\% dari jumlah peserta didik memperoleh nilai 70 ke atas.

Hasil Observasi Respon Peserta didik Siklus I dan Siklus II

\begin{tabular}{lrr}
\hline & \multicolumn{1}{c}{ Siklus I } & Siklus II \\
\hline Nilai & 2.490 & 3.035 \\
\hline Rata-Rata & 69,12 & 84,31 \\
\hline
\end{tabular}

Tabel di atas menunjukan bahwa penerapan model pembelajaran inkuiri dalam pembelajaran menganalisis unsur intrinsik teks cerpen mendapat respon yang positif dar peserta didik. Ini terbukti dari: Pemerolehan nilai rata-rata respon kelas pada siklus I adalah 69,12 dan pada siklus II meningkat menjadi 84,31. Jumlah peserta didik yang nilainya meningkat sebanyak 34 orang peserta didik. Persentase respon peserta didik dalam pembelajaran menganalisis unsur intrinsik cerpen dengan penerapan model pembelajaran inkuiri mencapai ketuntasan klasikal yaitu 94,44\% dari jumlah peserta didik memperoleh nilai 70 ke atas.

\section{PEMBAHASAN HASI PENELITIAN}

Berdasarkan pada refleksi siklus I yang dilakukan peneliti mengenai pembelajaran menganalisis unsur intrinsik teks cerpen dengan penerapan model pembelajaran inkuiripada peserta didik kelas XI MIPA 10 SMA Negeri 7 Denpasar tahun pelajaran 
2018/2019, ditemukan beberapa kendala yang dapat dilihat dari hasil pembelajaran yang tergolong cukup dengan rata-rata 73,42 dengan jumlah klasikal 24 orang peserta didik mencapai $66,67 \%$, hasil respon peserta didik dengan rata-rata 69,12. Dari hasil pembelajaran yang diperoleh pada siklus I masih terdapat kendala-kendala yang dihadap peserta didik. Mengatasi hal tersebut peneliti membuat perencanaan yang lebih baik dengan memperhatikan berbagai aspek pendukung yang berupa rancangan pembelajaran.

Dari hasil tes siklus I menuju siklus II menunjukkan adanya peningkatan hasil yang diperoleh peserta didik. Setelah proses pembelajaran pada siklus terlaksana, dapat dilihat dari adanya peningkatan hasil pembelajaran yang tergolong baik dengan skor rata-rata yang diperoleh 82,03 dengan jumlah klasikal peserta didik mencapai $94,44 \%$, hasil respon peserta didik dengan rata-rata 84,31 dengan jumlah klasikal 94,44\%. Dengan penerapan model pembelajaran inkuiri dalam proses pembelajaran harus mengacu pada prinsipprinsip: (1) pendekatan inkuiri mempunyai tujuan utama yaitu mengembangkan kemampuan berpikir. Oleh karena itu, pendekatan inkuiri berorientasi pada proses dan hasil belajar yang merupakan bagian dari pengembangan kemampuan berpikirnya, (2) pada proses pembelajaran dengan pendekatan inkuiri ada proses interaksi antar peseta didik, interaksi peserta didik dengan guru maupun interaksi antara siswa dengan lingkungan, (3) prinsip bertanya sangat penting dalam menerapkan pendekatan inkuiri ketika pembelajaran berlangsung, (4) belajar merupakan proses berpikir (learning how to think) yaitu proses mengembangkan kemampuan seluruh otak, (5) belajar sebagai proses untuk mencoba segala kemungkinan. Maka dari itu, peserta didik perlu diberi kebebasan untuk mencoba sesuai dengan perkembangan kemampuan logika dan penalarannya.

Jadi, penerapan model pembelajaran inkuiridapat meningkatkan kemampuan menganalisis unsur intrinsik cerpen pada peserta didik kelas XI MIPA 10 SMA Negeri 7 Denpasar tahun pelajaran 2018/2019. Selain itu, hasil penelitian ini juga menunjukan adanya peningkatan respon peserta didik terhadap penggunaan model pembelajaran inkuiridalam pembelajaran menganalisis unsur intrinsik cerpen dari siklus I ke siklus II.

\section{PENUTUP}

\section{Simpulan}

Penerapan model pembelajaran inkuiridapat meningkatkan kemampuan peserta didik menganalisis unsur intrinsik teks cerpenpeserta didik kelas XI MIPA 10 SMA Negeri 7 Denpasar tahun pelajaran 2018/2019. Hal ini dapat dilihat dari meningkatnya hasil belajar peserta didik pada hasil pra siklus, siklus I dan siklus II. Pada pelaksanaan prasiklus diperoleh nilai rata-rata 65,64, pada siklus I mengalami peningkatan rata-rata menjadi 73,42 dan pada siklus II nilai rata-rata 82,03. Berdasarkan hal tersebut penelitian tindakan kelas ini dapat dihentikan, karena sudah memenuhi kriteria dalam indikator keberhasilan.

Penerapan model pembelajaran inkuiri dapat meningkatkan kemampuan menganalisis unsur intrinsik mendapat 
respon yang sangat baik dari peserta didik kelas XI MIPA 10 SMA Negeri 7 Denpasar tahun pelajaran 2018/2019. Hal ini terbukti dari nilai rata-rata hasil observasi pada siklus I yakni 69,12 dan meningkat menjadi 84,31 pada siklus II. Peserta didik sangat terbantu dengan penerapan model pembelajaran inkuiri sehingga menggali perhatian, kedisiplinan, tanggung jawab, keaktifan dan kerjasama peserta didik dalam menganalisis unsur intrinsik teks cerpen.

\section{Saran}

Guru mata pelajaran bahasa Indonesia disarankan agar dapat mempertimbangkan menerapkan model pembelajaran inkuiri ini, karena pembelajaran seperti ini dapat melatih peserta didik dalam mengemukakan pendapat, maupun merespon peserta didik untuk mengembangkan kemampuan percaya dirinya. Guru selalu bersikap kreatif dan inovatif dalam menciptakan suasana yang mampu mengajak peserta didik untuk belajar dan guru juga selalu memotivasi peserta didik untuk gemar membaca karya sastra dengan memanfaatkan perpustakaan sebagai tempat membaca, sehingga nantinya kemampuan peserta didik dalam menganalisis unsur intrinsik cerpen dapat lebih ditingkatkan.

\section{DAFTAR PUSTAKA}

Aksan, Hermawan. 2015. Proses Menulis Kreatif Menulis Cerpen. Bandung: Nuansa Cendikia

Aminuddin. 2013. Pengantar Apresiasi Karya Sastra. Malang: Sinar Baru Algensindo

Arikunto,Suharsimi.2013. Dasar-dasar Evaluasi Pendidikan. Jakarta: BumiAksara.
Baharudin dan Esa Nur Wahyuni. 2007. Teori Belajar dan Pembelajaran. Yogyakarta: Ar-Ruzz Media

Hamzah B. Uno dan Masri Kudrat Umar. 2009. Mengelola Kecerdasan dalam Pembelajaran. Jakarta: Bumi Aksara.

Hayati dan Mansur, Muchlich. tt. Latihan Apresiasi Sastra Penunjang Pengajaran Bahasa dan Sastra Indonesia di SMP DAN SMA. Surabaya: Triana Media

Karmini, Ni Nyoman. 2011. Teori Pengkajian Prosa Fiksi dan Drama. Tabanan: Pustaka Larasan

Komalasari, Kokom. 2014. Pendekatan Kontekstual: Konsep dan Aplikasi. Bandung: Refika Aditama.

Koyan, I Wayan. 2012. Statistik Pendidikan Teknik Analisis Data Kuantitatif. Singaraja: Universitas Pendidikan Ganesha Press.

Kosasih E. 2012. Dasar-dasar Keterampilan Bersastra. Bandung: Yrama Widya Untuk Meningkatkan Kemampuan Menganalisis Unsur Instrinsik Cerita

Ngalimun. 2012. Strategi dan Model Pembelajaran. Banjarmasin: Aswaja Pressindo.

Nurgiyantoro, Burhan. 2013. Teori Pengkajian Fiksi. Yogyakarta: Gadjah Mada University Press.

Nurkencana dan Sunartana. 1992. Evaluasi Hasil Belajar. Surabaya: Usaha Nasional.

Pujiharto. 2012. Pengantar Teori Fiksi. Yogyakarta: Ombak.

Rusman. 2011. Model-Model Pembelajaran: Mengembangkan Profesionalisme Guru. Jakarta: PT Raja grafindo Persada.

Sanjaya, Wina. 2016. Strategi Pembelajaran Berorientasi Standar Proses 
Pendidikan. Jakarta: Prenadamedia Group.

Sugiyono. 2014. Metode Penelitian Kuantitatif Kualitatif dan $R \& D$. Bandung: Alfabeta.

Sukardi, H, M. 2015. Metode Penelitian Pendidikan Tindakan Kelas Implementasi dan Pengembangannya. Jakarta: PT Bumi Aksara.

Susanti, Ratna. 2013. Pedoman Pintar EYD Ejaan Yang Disempurnakan Terbaru. Klaten Utara: CV Mitra Media Pustaka.

arigan, Henry Guntur. 2015. Prinsip- Prinsip Dasar Sastra. Bandung: CV Angkasa.

Widja, I Gede. 1989. Dasar-Dasar Pengembangan Strategi serta Model- Model Pengajaran

Sejarah. Jakarta: Depdikbud Dirjen Dikti

Yohan, Herman Yosep, dkk. 2013. "Peningkatan Kemampuan Menganalisis Unsur Intrinsik Cerpen Melalui Pembelajaran Kooperatif Model Jigsaw Pada Siswa Kelas VII A SMP Budi Utama Tahun Pelajaran 2012/2013".

Yuliana, Erna. 2011. "Peningkatan menganalisis unsur intrinsik cerpen melalui model student teamsachievement divisions (STAD) kelas V SDN Juwet II Kabupaten Kediri”. 
